\title{
The Amazon Ocular Oncology Center: The first three years
}

\section{Centro de Oncologia Ocular do Amazonas: primeiros três anos}

\author{
Sabrina Cohen', Caroline S. Pretyman², Renato Sant'Ana ${ }^{3}$, Nakul Singh, Melina Morales³, Rubens N. Belfort ${ }^{3}$ \\ 1. Fundação Piedade Cohen, Manaus, AM, Brazil. \\ 2. Universidade Federal de São Paulo, São Paulo, SP, Brazil. \\ 3. Centro de Oncologia Ocular, Departamento de Ofalmologia e Ciências Visuais, Universidade Federal de São Paulo, São Paulo, SP, Brazil. \\ 4. Case Western Reserve University School of Medicine, Cleveland, Ohio, USA.
}

\begin{abstract}
Purpose: To evaluate the first three years of The Amazon Ocular Oncology Center, the first ocular cancer center in the North of Brazil. Methods: Here, we report patient information including patients' age, gender, diagnosis, treatment, and city of origin. Results: Two hundred and twenty-one patients were included on this study: $160(72 \%)$ patients came from the city of Manaus, 52 (24\%) from other cities in Amazonas, and 9 (4\%) from other states. Of the 221 patients, 150 (68\%) were afflicted with benign lesions and the remaining 71 (32\%) had malignant lesions. Benign diagnosis included pterygium, chalazium, conjunctival nevus, and papilloma, cataract, and retinal detachment. Of the malignant cases, squamous cell carcinoma (SCC) of the conjunctiva was the most frequent with 43 cases $(60 \%)$. Other diagnoses included choroidal melanoma (8 cases, $11 \%)$, retinoblastoma (7 cases, $9 \%$ ), lymphomas (5 cases, $7 \%$ ), basal cell carcinomas of the eyelid (4 cases, $5 \%$ ), conjunctival melanoma (2 cases, $2 \%$ ), and Kaposi sarcomas (1 case, $1 \%$ ). Of the 43 patients with SCC, the mean age was 62 years old, and $30(69 \%)$ were male; 29 patients $(67 \%)$ were treated with an excisional biopsy, and 14 (33\%) were treated with neoadjuvant topic chemotherapy, followed by surgery.
\end{abstract}

Keywords: Eye/pathology; Eye neoplasms; Carcinoma; Melanoma; Medical oncology; Amazon

RESUMO | Objetivo: Reportar sobre os primeiros três anos do Centro de Oncologia Ocular do Amazonas, primeiro centro de oncologia ocular na região Norte do Brasil. Métodos: Relatamos informações de diagnóstico, idade, sexo, tratamento e cidade de origem dos pacientes atendidos nos 3 primeiros

Submitted for publication: December 4, 2017

Accepted for publication: July 24, 2018

Funding: No specific financial support was available for this study.

Disclosure of potential conflicts of interest: None of the authors have any potential conflicts of interest to disclose.

Corresponding author: Rubens N. Belfort

Rua Botucatu, 822 - São Paulo, SP - 04023-062 - Brazil - E-mail: epm@belfort.med.br

Approved by the following research ethics committee: Universidade Federal de São Paulo (CAAE: 40254514.8.0000.5505). anos. Resultados: Identificamos 221 pacientes, dos quais 160 (72\%) eram da cidade de Manaus, 52 (24\%) de outras cidades do Amazonas e 9 (4\%) de outros estados. Dos 221 casos, 150 (68\%) eram lesões benignas e 71 (32\%) malignas. Lesões benignas incluíram pterígio, calázio, nevus e papiloma de conjuntiva, catarata e descolamento de retina. Das lesões malignas a mais comum foi o carcinoma escamoso de conjuntiva com 43 casos (60\%). Outros diagnósticos incluíram melanoma de coróide (8 casos, $11 \%$ ), retinoblastoma ( 7 casos, $9 \%$ ), linfomas ( 5 casos, $7 \%$ ), carcinoma da pálpebra (4 casos, $5 \%$ ), melanoma da conjunctiva ( 2 casos, $2 \%$ ) e sarcoma de Kaposi (1 caso, $1 \%$ ). Dentre os CEC de conjuntiva, a idade media foi de 62 anos e 30 pacientes (69\%) eram do sexo masculino. Vinte e nove casos $(67 \%)$ foram tratados com biópsia excisional e 14 (33\%) com quimioterapia tópica neoadjuvante seguida de cirurgia.

Descritores: Olho/patologia; Neoplasias oculares; Carcinoma; Melanoma; Oncologia; Amazonas

\section{INTRODUCTION}

In 2013, the first ocular oncology center in northern Brazil was founded in the city of Manaus, the capital of the state of Amazonas. This region of Brazil has a population of 15,864,454 inhabitants in an area of 1,571,000 km, of which the Amazonas state has a population of $3,483,985$ people $^{(1)}$. The main challenge to providing healthcare to this area is its remote location, the main transportation being boats on the river, with trips taking up to 19 hours. Many of these areas are inaccessible by plane, and most patients cannot afford expensive journeys to main medical centers in the southern regions of the country, or depend on government funding that can take months, resulting in the worsening prognosis of patients with cancer.

The ocular oncology center was the result of collaboration between the Piedade Cohen Institute in Manaus, the Federal University of São Paulo, and the Champalimaud Foundation from Portugal. The center was desig- 
ned to receive uninsured patients referred by doctors from all the states of northern Brazil for concerns of ocular malignancy. Before the Ocular Oncology Center was inaugurated, these patients had to travel long distances to other cities, such as Salvador, Recife, or São Paulo, to receive treatment.

The most common ocular cancers in this equatorial region are believed to be retinoblastoma (RB) in the pediatric population and squamous cell carcinoma (SCC) of the conjunctiva in the adult population ${ }^{(2)}$. Other ocular cancers in the adult population include melanoma and lymphomas. The main risk factor for $\mathrm{RB}$ is a positive family history and it is not related to the equatorial region $^{(3)}$. SCC has many risk factors, including exposure to ultraviolet (UV) radiation. Therefore, a higher incidence is observed in countries close to the equator ${ }^{(4,5)}$.

The purpose of this study was to report the number of cases and the characteristics of the population, and to describe the most common ocular diagnoses made by this new ocular oncology center during the first three years of operation. Also, the percentage of the expected cases seen at the center is reported. This information will allow better recognition and planning to provide better oncologic care in northern Brazil.

\section{METHODS}

After IRB approval, all medical records of the patients were retrospectively examined at the Center of Ocular Oncology of Amazonas from 2014 to 2016. An ocular oncologist from Hospital São Paulo (Escola Paulista de Medicina) traveled to Manaus every six weeks to examine pre-screened patients who were referred from an ophthalmologist in northern Brazil. Our team member in Manaus was an ophthalmologist who received four weeks of ocular oncology training in São Paulo. Patients were re-examined when the São Paulo staff was present and operated on the next day if necessary. Data analyzed included patients' age, gender, diagnosis, treatment, and city of origin.

\section{RESULTS}

We identified 221 patients who were included in this study: 160 (72\%) patients came from the city of Manaus, 52 (24\%) from other cities in Amazonas, and 9 (4\%) from other states. Of the 221 patients, 150 (68\%) had benign lesions and the remaining 71 (32\%) had malignancies. Of the malignant cases, SCC of the conjunctiva was the most frequent, with 43 cases $(60 \%)$. Other diagnoses included choroidal melanoma (8 cases, $11 \%)$, RB (7 cases,
$9 \%)$, ocular adnexal lymphoma (5 cases, 7\%), basal cell carcinoma of the eyelid ( 4 cases, $5 \%$ ), conjunctival melanoma (2 cases, $2 \%$ ), and Kaposi sarcoma (1 case, $1 \%$ ) (Figures 1 and 2).

Among the 43 patients with SCC, the mean patient age was 62 years (range: 34-95 years), and $30(69 \%)$ patients were male. Of the patients with SCC, 29 (67\%) received an excisional biopsy, and 14 (33\%) were treated with neoadjuvant chemotherapy, with topical mitomycin $0.02 \%$ administered at one drop four times a day for 14 days, followed by surgery with cryotherapy on the conjunctival margins. Mitomycin was used as neoadjuvant therapy when the tumor was too large to be resected or if surgery would take longer to be performed.

We found 8 cases of uveal melanoma, with a mean patient age of 52.5 (range: 20-55); 6 (75\%) were male. All patients were treated with enucleation because plaque brachytherapy is not available in the public medical system in Brazil.

We observed seven RB cases, with a mean patient age of 19.8 months (range: 7-36 months); 3 (43\%) patients were male and all seven presented with the advanced extraocular disease.

\section{DISCUSSION}

This case series of our oncology center in Manaus is the first study of ocular oncology in northern Brazil. Most patients in this study are from Manaus, with a smaller fraction from the rest of the Amazonas state, and an even smaller fraction from other states. This is expected given
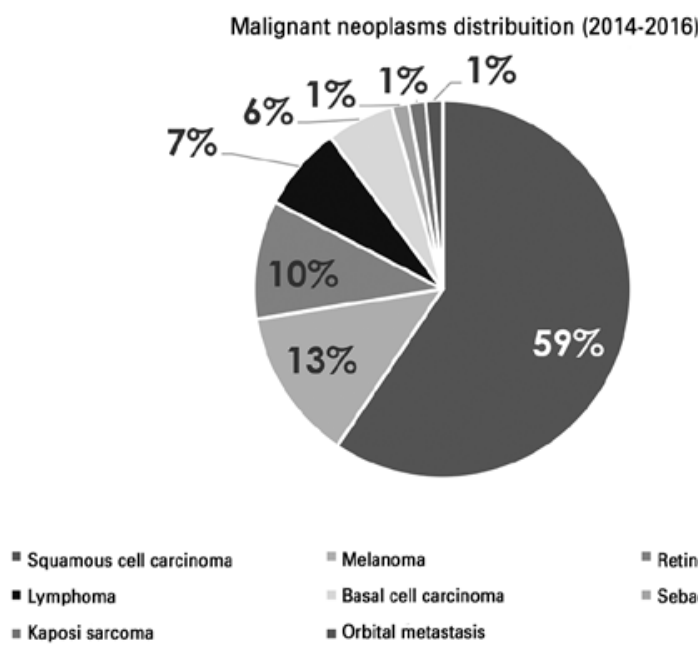

" Retinoblastoma

" Sebaceous carcinoma

Figure 1. Distribution of malignant neoplasm diagnosis in the Oncology Ocular Center of Manaus between 2014 and 2016. 

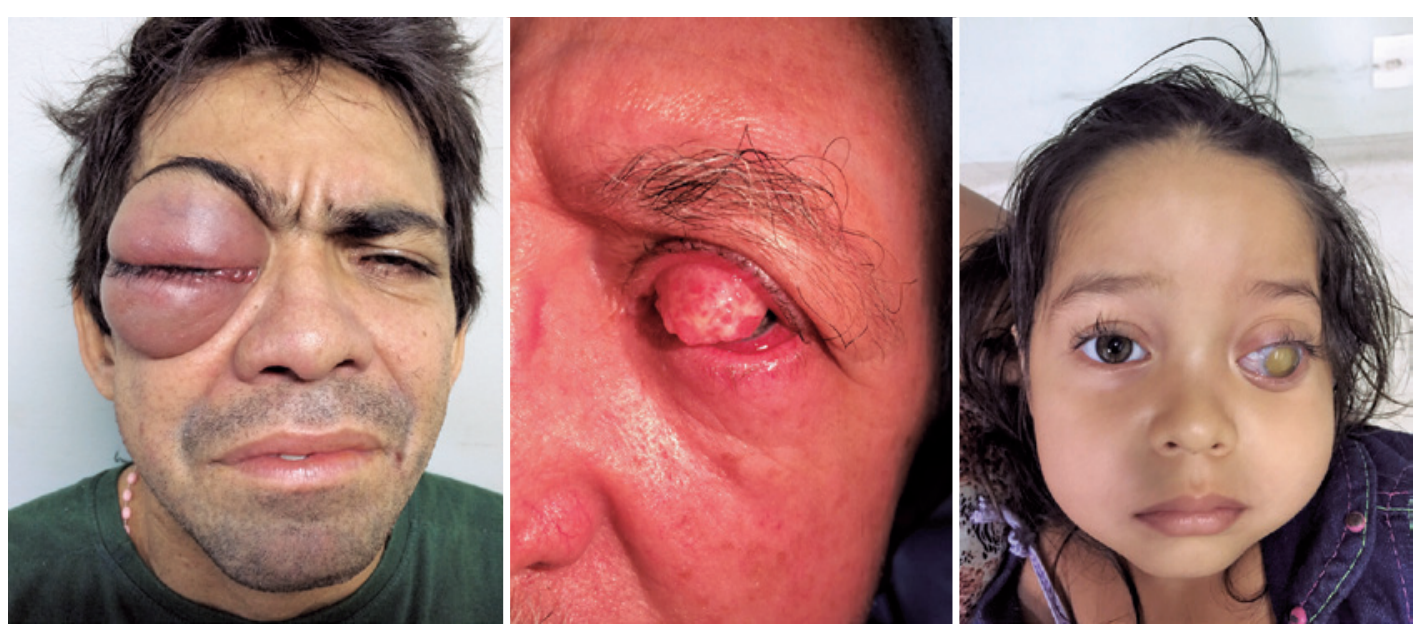

Figure 2. Illustrative cases from the Ocular Oncology Center of Manaus: orbital lymphoma (left), squamous cell carcinoma (center), and retinoblastoma (right).

that most of the population of the state is concentrated in Manaus (52\%), with the remaining distributed over a large area and have difficulty in accessing the capital city. Moreover, we would expect that knowledge of our center will take time to reach more geographically isolated areas.

Of the malignancies identified, SCCs were the most frequent ocular cancer found in $43(60 \%)$ of the 71 malignant lesions. While data on SCC incidence in this region are not available, we calculated that there would be 313 new cases in a three-year period in Amazonas ${ }^{(6)}$. Therefore, we estimate that we received $12 \%$ of the new cases. That this series includes such a small fraction of all estimated cases could be accounted for by the fact that less complex cases are treated by general ophthalmologists, with no need for referral to a specialized center or merely because the poor ophthalmologic care in the area prevents these patients from receiving medical attention.

The demographics of the patients with SCC in our series are mostly consistent with the current literature, with most cases occurring in males (69\%). This preponderance among males is explained by more outdoor labor being performed by men, resulting in a greater degree of UV exposure.

We had no incidence of uveal melanoma in the Brazilian population, but given the incidence of uveal melanoma in the North American population ${ }^{(7)}$, we expect to observe 45 cases of uveal melanoma over a three-year period. However, we observed 8 cases, $20 \%$ of our prediction. This discrepancy can be explained by the ethnic profile of our population, which is a mix of Caucasians and indigenous peoples, and African descendants. African and indigenous populations are known to have lower rates of incidence of uveal melanoma ${ }^{(8)}$. Additionally, remote areas of this region lack access to ophthalmologic care, where a fundus exam could identify posterior lesions. This lack of access to basic ophthalmologic care could further explain the lack of metastatic intraocular lesions in our study, which we would expect to be the most common intraocular malignancy ${ }^{(9)}$.

Our series includes 7 cases of RB; based on an incidence of 5.0 cases per million children aged 0-14 years (95\% confidence interval: 3.5-6.4) ${ }^{(10)}$, we would expect 15 cases in the Amazonas state in the 3-year period (estimated Amazonas state population of 1.1 million people aged 0-14 years) $)^{(1)}$. Compared to the other cases of ocular malignancy, we estimate that we observed roughly half of all RB cases in the area. We attribute this relative success to the recently opened ocular oncology center and the aggressive nature of the disease, which causes a wide range of symptoms if left untreated, including strabismus, proptosis, and painful blind eyes. In this series, the patients with RB were uniformly diagnosed with the advanced extraocular disease and were sent to São Paulo for treatment because of the extreme complexity of the disease and the multidisciplinary teams necessary for treatment, not otherwise available in northern Brazil.

\section{CONCLUSION}

This is the first investigation into ocular oncology occurring in the northern area of Brazil. Carcinomas represented most of the cases, which is consistent with 
the previous epidemiological literature. Unfortunately, due to the difficulty in accessing ophthalmologic care in the area, all RB cases were diagnosed in advanced stages, with poor life prognosis. We hope that our center will continue to promote more referrals to afford earlier diagnosis and better prognosis to this population.

\section{REFERENCES}

1. Instituto Brasileiro de Geografia e Estatística (IBGE). Sinópse do Censo Demográfico 2010 [Internet]. Brasília (DF); IBGE; 2018. [citado 2018 Ago 1]. Disponível em: https://censo2010.ibge.g.,ov.br/ sinopse/index.php?dados $=4 \& u f=00$

2. Newton R, Ferlay J, Reeves G, Beral V, Parkin DM. Effect of ambient solar ultraviolet radiation on incidence of squamous-cell carcinoma of the eye. Lancet. 1996;347(9013):1450-1

3. Jemal A, Devesa SS, Fears TR, Fraumeni JF Jr. Retinoblastoma incidence and sunlight exposure. Br J Cancer. 2000;82(11):1875-8.

4. Tulvatana W, Bhattarakosol P, Sansopha L, Sipiyarak W, Kowitdamrong
E, Paisuntornsug T, et al. Risk factors for conjunctival squamous cell neoplasia: a matched case-control study. Br J Ophthalmol. 2003; 87(4):396-8.

5. Ateenyi-Agaba C, Franceschi S, Wabwire-Mangen F, Arslan A, Othieno E, Binta-Kahwa J, et al. Human papillomavirus infection and squamous cell carcinoma of the conjunctiva. $\mathrm{Br}$ J Cancer. 2010;102(2):262-7.

6. Gichuhi S, Sagoo MS, Weiss HA, Burton MJ. Epidemiology of ocular surface squamous neoplasia in Africa. Trop Med Int Health. 2013; 18(12):1424-43.

7. McLaughlin CC, Wu XC, Jemal A, Martin HJ, Roche LM, Chen VW. Incidence of noncutaneous melanomas in the U.S. Cancer. 2005; 103(5):1000-7.

8. Tsai T, Vu C, Henson DE. Cutaneous, ocular and visceral melanoma in African Americans and Caucasians. Melanoma Res. 2005; 15(3):213-7.

9. Bloch RS, Gartner S. The incidence of ocular metastatic carcinoma. Arch Ophthalmol. 1971;85(6):673-5.

10. Moreno F, Sinaki B, Fandiño A, Dussel V, Orellana L, Chantada G. A population-based study of retinoblastoma incidence and survival in Argentine children. Pediatr Blood Cancer. 2014;61(9):1610-5. 